\title{
A INCORPORAÇÃO DA AMAZÔNIA AO IMPERIO.
}

A independêndia do Brasil, a darmos crédito à generalidade dos que vêm estudando aquêle momento decisivo da formação nacional, foi alcançada sem as dificuldades que marcaram o episódio eqüivalente na América inglêsa e na América espanhola, num verdadeiro entendimento amistoso entre portuguêses e brasileiros, espécie de maior idade alcançada e aceita sem restrições de vulto pelos que haviam criado a nação em três séculos de colonização intensiva.

Ora, a compreensão do movimento da independência, em face do que realmente ocorreu aqui e ali, não pode ter êsse caráter simplista. Porque em vários pontos do Brasil, verificaram-se incidentes que deram, ao episódio, sentido militar, significação heróica, do mesmo modo porque evidenciaram a existência de resistências políticas fortíssimas, vencidas em luta franca, demonstrativas do estado d'alma nacional, perfeitamente estruturado e identificado com a nova realidade que surgia.

As fôrças econômico-financeiras do país, às vésperas do Sete de Setembro, estavam quase inteiramente em mãos do elemento reinol. Essas fôrças, por todos os meios, procturaram defender os interêsses da mãe pátria, inclusive proporcionando os meios necessários à reação militar que veio a furo em várias províncias, como a Cisplatina, a Bahia, o Piauí, o Maranhão e a Amazônia. Reação, no final de contas, que exigiu ações de guerra, cuja história pormenorizada não se fêz ainda, do que vêm resultando, grosso modo, as afirmações apressadas, da independência obtida, suavemente, por acôrdo entre as partes litigantes.

Na Amazônia, a reação apresentou seus aspectos memoráveis. $E$ determinou o aparecimento de resistências, que revelaram o estado de consciência cívica que dominava aquela grande área social do Brasil e constituem um dos vários sucessos que nos levam a discordar dos historiadores que entendem a independência sob aquele prisma simplista.

E' preciso, inicialmente, recordar que a incorporação do extremo-norte do Brasil à comunhão imperial lusitana cons- 
tituiu um dos episódios distintos na história da formação brasileira.

Parte integrante, pelo ajuste tordesilhano, da soberania espanhola, a Amazônia foi conquistada pelo esfôrço de sertanistas, militares, funcionários do estado, religiosos, colonos, pelo desenvolvimento de um amplo programa imperial, que os homens do govêrno português estudaram e realizaram com uma constância memorável. Assim, antes de ser uma emprêsa efetuada como decorrência da expansão natural que tanto distinguiu outros setores territoriais do Brasil, a emprêsa amzônica foi uma emprêsa oficial. E disso resultou que, ajustadas pelas vias diplomáticas ou pela ação militar, vencidas as tremendas dificuldades impostas pelo meio geográfico, o domínio lusitano era, ao findar o período colonial, uma realidade que tinha seus índices numéricos no vulto do comércio que a colônia mantinha com a mãe pátria e em mil outras particularidades que lhe davam características particulares no quadro das unidades políticas do Reino que D. João viera estabelecer, no Novo Mundo, com os elementos que os três séculos de colonização proporcionaram.

Ora, sendo a Amazônia um foco rico de lusitanidade, constituindo uma unidade política distante do Brasil, como explicar sua incorporação ao Império?

Desde logo não ignoremos também que em meio a essa caracterização de lusitanidade, a Amazônia era um dos campos sociais marcados mais intensamente pela miscigenação intensiva, que se processara sob incentivos do poder público. A multidão mestiça, mestiça de gentio e de reinol, era vultosa. Constituia, mesmo, o grosso, o fundamento maior da população. Essa multidão vivia uma vida de distância com relação ao reinol, que exercia as funções públicas e, mais que isso, possuia o senhorio da terra, da produção, era o detentor da riqueza. Essa multidão, segundo apurara, no decorrer do ano de 1820, num inquérito sensacional, um funcionário do govêrno português, experimentaria padecimentos incríveis, permanecendo em verdadeiro estado de escravidão, inclusive nos estabelecimentos industriais do Estado. Ora, tal estado de coisas bem podia constituir um ambiente propício para qualquer atuação revolucionária. Porque, em face de tamanhas distâncias sociais, os não reinóis eram um elemento magnífico para ser utilizado na aventura política, mesmo não possuindo êle os esclarecimentos culturais que explicassem gestos políticos, atitudes menos primárias que um simples ajuste de contas em hora oportuna.

Com a revolução constitucionalista do Pôrto, que irradiou sôbre Portugal e sôbre o reino de D. João VI no Bra- 
sil, encontrou, a Amazônia, a oportunidade de que vinha carecendo para encerrar essas distâncias sociais e políticas? 0 velho organismo absolutista que dominava o pensamento $e$ a maquinária política da Europa, destruído pela manifestação do liberalismo que a Revolução Francesa lançou ao mundo, não estava montado, no vale, com um aparato que dava a idéia de ser impossível destruturá-lo, desmontá-lo?

A Amazônia, com o advento de D. João, começara a aproximar-se do Brasil. Começara. As ordens emanavam do Rio, sede da Côrte; as relações econômicas, mais largas, com as conquistas democráticas de Cairú, também se deslocando pa$\mathrm{r}:$ o Reino Americano, é certo que muito vagarosamente, tinham criado êsse relacionamento que já se vinha observando. Mas era o espírito de Portugal que animava todo o ser da região. Tudo se criava, tudo se organizava com os olhos voltados para o cantinho da Ibéria. Tanto mais quanto com o trecho europeu da monarquia se operavam ainda os melhores entendimentos econômicos.

$\mathrm{O}$ liberalismo de $\mathrm{D}$. João e de seus ministros, à frente dêles êsse simpático e dinâmico Souza Coutinho, Conde de Linhares, chegara à Amazônia contido, ùnicamente, nos votos, nas esperanças, nas instruções para o bem da coletividade.

A Capitania de São José do Rio Negro, estiolando-se pelo desgovêrno dos homens mandados gerí-la, desde 1818 suplicava a sua autonomia e uma série de atos que lhe dessem a vitalidade por que ansiava. No Grão-Pará, não se adiantara um passo em civilização política. O Conde dos Arcos, desanimado, esgotado, aos inícios do século XIX confessara êsse estado de coisas. Votos, esperanças, instruções e a nada mais se reduzia, assim, o sôpro do sistema novo que sacudia o Novo Mundo. $\mathrm{O}$ organismo absolutista, de pé alicerçado, respirava bem, a sete fôlegos. E com o absolutismo, o domínio de Portugal. O idealismo contido na doutrina liberal não se instalara na Amazônia. A passagem política permanecia a mesma. Não havia imprensa, que o divulgasse. A incultura popular era imensa. O que se sabia e se escondia, medrosamente, sôbre o estado de coisas que alterava a fisionomia social do Velho Mundo, conseguia-se no informe manhoso de viajores, de marujos, talvez numa ou noutra notícia cavilosa transmitida pelos franceses da Guiana. A política da porta-fechada, das precauções policiais contra as novidades do Velho Mundo, não cessara.

Felipe Alberto Patroni Martins Maciel Parente, "paraense nato", bacharel pela Universidade de Coimbra, entusiasta da Revolução do Pôrto, "ardente, corajoso, idealista", 
desembarcando em Belém, em fins de dezembro de 1820, iniciou a propaganda contra o velho e ruinoso regime absolutista.

Num ambiente decididamente trancado às incursões dessas novidades extremistas, como seria entendido o constitucionalismo, Patroni não encontrou, todavia, embaraços sérios a remover.

A Junta que governava o Estado, e se notabilizava pelas imprudências, pelos desatinos, não the impediu a semeadura demagógica, compreensíveis pelas ligações de amizade e parentesco de Patroni com dois dos cinco membros dela. A quantos se dirigiu, a quantos Patroni passou a contar para a sua facção, que dispôs, logo, de fortes elementos militares.

Mas como explicar essa frutificação tão rápida?

O contrabando espiritual sôbre o fermento político da Europa, passado dos barcos que ligavam a Amazônia à Europa e a Pernambuco, teria preparado o ambiente,? Em meio de tão escuro clima espiritual êsse contrabando poderia ser realidade? O exemplo nordestino de 1817 teria provocado algum anseio político? O exemplo dos exércitos libertadores da Venezuela e do Perú que avançavam sôbre a fronteira com o Brasil, obrigando à movimentação de tropas e a um verdadeiro sobreaviso, teria eco na Amazônia? Evidentemente tôdas essas razões devem ser devidamente estimadas, dado que explicam o acontecimento. E' certo que Patroni imaginava uma éra em que as "responsabilidades pessoais fôssem definidas e efetivas", dentro de um aparelhamento governamental sem as contrações ainda em vigor e alicerçado tudo na indissolubilidade dos laços políticos de Portugal e Brasil. Era de liberdades, mas ainda de união entre brasileiros e portuguêses.

Os portuguêses, à sua palavra, olharam o exemplo que vinha da Europa e era preciso seguir na América Portuguêsa. Ainda o respeito às diretrizes da Península. Os brasileiros atenderam, sente-se bem êsse estado d'alma, a que se podiam romper, agora, os laços de ferro do absolutismo, caminho seguro contra o domínio lusitano. Foi assim na Amazônia. Foi assim em todo o resto do Brasil. Demais, razão particular, lccal, razão muito forte, de certo a que mais importou no momento para a unânimidade de vistas que se observou, abriase uma oportunidade para se verem todos livres da Junta Governativa, que vexava, que intranquilizava a coletividade amazônica, e do Conde de Vila Flor, que dum momento para outro poderia voltar para reassumir o govêrno da Capitania, de que se afastara momentâneamente para uma ida à Côrte do Rio de Janeiro. 
A revolução, concertada na loja do comerciante José Batista da Silva, estalou na manhã de 1 de janeiro de 1821, por c'asião de uma revista que deveria ser passada à guarnição di capital.

O alferes de milícia Domingos Simões da Cunha, baiano, comerciante, seguido de outros conjurados, à formatura do $1^{\circ}$ regimento de infantaria, gritou-lhe: "Viva a Religião Católica. Viva El-Rei. Viva a Constituição". Depois de ligeira vacilação, o coronel João Pereira Vilaça, comandante, envolvido também na conspiração, respondeu num "Vivam as Côrtes", que tropa acompanhou. Tocado rebate, as demais unidades que foram chegando aderiram. Seguiu-se a deposição da Junta, promovida pelo coronel Francisco José Rodrigues Barata, outro dos conjurados, comandante do $2 .^{\circ}$ regimento de infantaria.

No palácio do govêrno, presentes o povo e a tropa, o senado da Câmara de Belém, o vigário capitular Romualdo Antônio de Seixas, por proposta do Coronel Barata foi escolhido o negociante Manuel Joaquim do Nascimento para, na qualidade de juiz do povo, "inquerir quais os cidadãos que o mesmo desejava para o novo govêrno constitucional provisório".

Sob aclamações, ficou organizada a Junta Provincial, que prestou juramento perante o senado da Câmara, integrando-a: o vigário Romualdo Antônio de Seixas, que até a hora do movimento permanecia inteiramente alheio ao que se planejava, presidente; juiz de fora Joaquim Pereira de Macedo, vice-presidente; coronéis Francisco José Rodrigues Barata e Giraldo José de Abreu, proprietários João da Fonseca Freitas e José Ruiz d€ Castro Goes, comerciante Francisco Gonçalves Lima, e tenente-coronel Francisco José de Faria, vogais.

Correu tudo num ambiente entusiástico, sem derramamento de sangue, sem um gesto enérgico em defesa da Junta Governativa. Se todos ansiavam por ver-se livres dela! Brasileiros e portuguêses, de mãos dadas, compunham a administração. Tôda a Amazônia aderiu ao golpe dos conjurados de Belém. Apenas no Rio Negro houve necessidade de depor o governador Manuel Joaquim do Paço, que se negara a aceitar os acontecimentos, fiel ao absolutismo, em que educara o espírito. Sem que corresse sangue também.

Nos primeiros tempos, não foi pequeno o nervosismo, entre os próprios membros do Govêrno revolucionário, receiosos de ter dado um passo em falso adiantando-se ao encôntro dos constitucionalistas do Reino sem conhecer o pensamento de D. João e de seus ministros da Côrte do Rio de Janeiro. Realmenteí fôra uma atitude avançada, perigosa 
mesmo. Em breve, porém, à notícia de que a idéia renovadora se alastrava ou era vitoriosa na própria capital americana, aquietara 0 ambiente, nesse particular.

Não seria possível à Junta, nesse instante, em meio às preocupações políticas executar um programa de intensos trabalhos construtivos. O momento era delicado. Patroni, agitadiço, inquieto, não se mostrava satisfeito. Entendia que a Amazônia deveria materializar mais vivamente o seu amor ao novo regime com uma representação imediata perante as Côrtes de Lisboa.

Às suas razões, no estilo gongórico, mas enérgico, que lhe retratava fielmente o ânimo fogoso, a Câmara de Belém, para cujo pronunciamento apelara, agiu, de certo, com muito critério. Não lhe cabia averiguar, decidir do assunto. Afetou, por isso, o caso à Junta Provisória, que entendeu apressada a medida, cabível, no seu entender, apenas quando entrasse em vigor uma lei que regulasse o assunto. Eram as primeiras dúvidas, as primeiras dificuldades que surgiram. Demais, exaltados queriam logo a demissão de todos os portuguêses, considerados suspeitos ao sistema político. Outros cresciam, na ousadia, a exigir a renúncia de $\mathrm{D}$. Romualdo da presidência da Junta. O prelado, aos olhos dêles, pulsava pelos reinóis. Portanto!

Os primeiros sintomas de nativismo lavraram por êsse tempo, como se percebe, pensando os patriotas "na necessidade de assumir os postos elevados da administração pública, então na sua maioria ocupados pelos portuguêses". A Junta sentiu o perigo da situação, que se apresentava, realmente, delicada, uma vez que o próprio Patroni, no dizer de pósteros, era alma danada contra os rumos que ela imprimia aos engócios da administração. Para conciliar as coisas, os poderosos serviram-se, então, de um manifesto: os paraenses deviam ter confiança nos destinos da pátria e seus dirigentes e não dar ouvidos aos que procuravam subverter a ordem sem maior ideal que os próprios interêsses.

As palavras da proclamação teriam produzido o efeito desejado? Parece que não. O ambiente não se mostrava sereno. A política a seguir não seria, de certo, a das violências. A Junta, armando-se contra o bote dos pasquineiros, que enchiam a cidade de papeluchos incendiários, organizou, a essa altura, uma "Junta Censitória, com poderes para proceder à censura de todos os papéis que têm de ser publicados nesta Capitania". Mas, seguiu a política da prudência, da habilidade, com relação a Patroni. Elemento turbulento por excelência, no juizo dos governantes, faziase mister retirá-lo do Pará. A Junta Provisória, num golpe de habilidade, nomeou-o procurador junto às Côrtes em 
Lisboa. Ele pleiteara o posto político de deputado: Todavia, credenciado como procurador, aceitou a missão, seguindo para a Europa, com poderes para suplicar quanto fôsse "compatível com as circunstâncias desta Província", cercado dos louvores da Junta, que o apresentava, para uso externo, como um patriota que, "munido dos desejos de ser útil à sua Pátria, há trabalhado com luzes".

A êsse tempo, livre de Patroni que, percebe-se, lhe dava dores de cabeça, a Junta abandonava aquela política hábil, maneirosa, das explicações, das falas ao povo, enveredando pelas violências individuais. Embora, os elementos que a combatiam não se arreceiavam de vexames. Os boletins continuaram, criando, para os membros do govêrno, uma atmosfera de antipatias e de ridículo. Tudo era motivo para essas explosões que exteriorizavam os produtos nativistas. A Junta Censitória fracassava redondamente. Sentia-se o clima pesado. Compreendendo o perigo das reivindicações de amor, de fidelidade a Portugal, entregou, a 20 de junho de 1821, o comando geral da tropa ao coronel João Pereira Vilaça, português, providência através da qual procurava, naturalmente, um apôio, frente às dificuldades que estavam surgindo.

A Câmara de Belém e as das outras vilas, tanto no GrãoPará como no Rio Negro, permaneceram, é certo, em mãos do elemento português. Embora, a 17 de julho, afetada pelas paixões políticas que tomavam corpo, criando facções que ameaçavam agitar a Província, a Junta solicitou a Lisboa a competente substituição, confessando-se incapaz de fazer serenar os ânimos. O emprêgo da violência parecia-lhe perigoso. $\mathrm{E}$ sem a política da violência não se poderia manter. $O$ trabalho dos maquis amazônicos era incessante.

Contra ela, a êsse tempo, abria campanha o ouvidor Antônio Maria Carneiro e Sá, que se destacava no cenário regional por uma série de arbitrariedades quando de sua atuação como membro da Junta Governativa que sucedera ao Conde de Vila Flor. Contra ela, parece que movimentados pelo ouvidor, tinham sido endereçadas representações às Côrtes, acusando-a de violenta, de incapaz, de ruinosa aos interêsses da coletividade regional. Evidentemente, a Amazônia entrava numa fase agitadiça.

$\mathrm{Na}$ Europa, Patroni, que movimentara a região para o constitucionalismo, apresentara-se à Regência do Reino e às Côrtes. Fora ouvido religiosamente. Se era o primeiro delegado que o Brasil enviava! Falara com a mesma impetuosidade de sempre. A Regência enchera-se de justa alegria com a atitude de sua colônia americana. As Côrtes também se tinham manifestado assim. Estas, examinando 
as credenciais de Patroni e de Domingos Simões da Cunha, que também fôra expedido ao Reino para cientificá-las dos sucessos de Belém a $10^{\circ}$ de janeiro de 1821 , tinham votado que a Junta Paraense bem podia the ter confiado poderes que dessem a condição de delegados da vontade popular. Assim houvesse sido e os dois procuradores estariam como deputados, pugnando legalmente pelas causas do vale. Mesmo assim as Côrtes lhes tinham autorizado a estar presentes às sessões, tomando assento entre os representantes da soberania nacional. Deferências, no fim de contas, que não deviam deixar de ser anotadas, mas não influiram decisivamente, no ânimo de Patroni, para afastá-lo de seus propósitos liberais. Pensamento desordenado, moço, ardoroso, voltava-se êle para a idéia de Portugal e Brasil unidos, entendendo-se, vivendo harmônicamente. E o que foi observando em Lisboa foi um caminhar quase vertiginoso para o retôrno do Brasil à condição de colônia, de onde se esperava apenas a contribuição econômica. Fazia campanha lá contra a Junta de Belém. Infrutiferamente, é certo, atribuindo-se um prestígio imenso, na sua Amazônia. "Eu quisera ser o Penn do Pará", dissera certa vez. Apresentara às Côrtes um projeto sôbre as eleições na Amazônia, pleiteando, em favor dos próprios escravos, o direito de voto. Pelas colunas do "Indagador Constitucional", em Lisboa, argumentou fortemente em tôrno do projeto, alargando-se em considerações a respeito das condições que distinguiam $o$ ambiente geo-político da Amazônia. Para o vale, assinalou, havia, por isso, necessidade de um processo todo especial, qual o que submetia à consideração dos Constituintes. Graças a essa sua atividade, as Côrtes tinham determinado a realização de eleições nas Províncias brasileiras, atendendo, em parte, para a Amazônia, às razões que apresentara e justificara tão calorosamente.

Patroni, é tempo de lhe tentarmos um perfil, pelo que nos deixou e através do pronunciamento de seus contemporâneos, nascera no Acará. Cursara as aulas do Seminário de Belém. Discípulo, em filosofia e retórica, de D. Romualdo Antônio de Seixas, revelou-se inteligente, aplicado. De sua passagem pela Universidade de Coimbra nada se sabe. Diziam-no bacharel. Seus biógrafos dão-no como estudante, às vésperas de formatura. Apresentava-se como autor intelectual do movimento de $1 .^{\circ}$ de janeiro, o que muitos contestavam, dando-lhe apenas a responsabilidade de animador, de semeador da demagogia. Vaidoso, ambicioso, pintam-no muitos, afirmando-se que incidentara com o coronel Barata por querer participar da Junta Provisória. Era tumultuário, descompassado, impetuoso. Esse descontrôle, 
encontramo-lo bem visível na produção literária que nos deixou, desconexa, absurda. "De espírito ardente, entusiasta, escreveu o Barão de Guajará, exaltava-se com a menor contrariedade às suas opiniões", instruído e de honestidade inquebrantável, nunca se deixava corromper pelo sórdido interêsse, nem também tentar corromper a ninguém, laborioso e econômico, passava a vida, sem luxo nem ostentação".

Para Carlos Pontes, Patroni foi um "vesânico e fulgente, saturado de letras clássicas, tendo na memória todos os livros sagrados, falando e escrevendo o latim, como se fôra a língua vernácula". Dom Romualdo de Seixas proclamou-o "moço de raro talento mas pouco feliz no uso que dêle tem feito".

Patroni, não há que duvidar, no exame imparcial que lhe tentamos da atuação, negado por uns, exaltado por outros, êle próprio exigindo a admiração da posteridade pelos serviços à Nação, foi uma figura impressionante. Sem êle com as atitudes exaltadas, nervosas, promovendo o compromisso dos elementos militares de Belém em tôrno do constitucionalismo, a Amazônia não teria proclamado, a $10^{\circ}$ de janeiro, a queda do regime absolutista. De atuação dinâmica, às escancaras, dominado de acendrado amor à pátria, ia ser, cercado da popularidade que o acompanhou até a quarta década do século XIX, a voz que deveria reunir os patriotas para a conquista da independência.

A Junta Provisória, ciente do que êle afirmava, na Metrópole européia, contra os que a integravam, em correspondência com o Soberano Congresso acusou-o fortemente, taxando-o de ambicioso, covarde, intrigante, ignorante, maquiavélico, perigoso ao sistema constitucional. Espécie de inimigo número um da ordem vigente. Pois se pretendia a independência e a igualdade entre brancos e negros! No fim de contas, com as tintas carregadas do retrato, a Junta fazia-lhe o maior elogio.

Sob sua inspiração, os irmãos João, Julião e Manuel Fernandes de Vasconcelos, paraenses, moços como êle, também idealistas, regressando do Reino, deram comêço em Belém, em outubro de 1821, a uma propaganda intensa contra o regime. Fizeram circular uma proclamação anônima, a serviço dessa ideologia, concitando os paraenses a romper em hostilidades contra os portuguêses. Fizeram circular outros papéis incendiários, que fomentavam a indisciplina e preparavam o advento da independência. De Patroni era uma circular, encimada por uma mão branca e outra negra, entrelaçadas, simbolizando a união das duas raças, concitando o cônego João Batista Gonçalves Cam- 
pos, a quem se imputava o crime de, na própria residência, praticar abusos, que se percebe seriam conciliábulos políticos. Os irmãos Vasconcelos, sério perigo aos interêsses portuguêses, denunciados pela Câmara Municipal da capital e pelo comerciante português José Ribeiro Guimarães, foram presos em novembro, submetidos a processo e remetidos para Portugal. Seria bastante para conter os anseios libertários que iam em crescendo assinalável?

Patroni, no Reino, continuava na defesa dos interêsses de sua terra. Ousara apresentar-se a D. João VI e, em tom impetuoso, dissera-lhe duras verdades: "Falemos claro, Senhor, todos querem obedecer à lei e não ao capricho: todos querem ser bem governados. Se um ministério pela sua negligência ou despotismo, apresenta um govêrno tirano, os povos desesperam e sacodem o jugo. Os povos não são bestas, que sofrem em silêncio todo o pêso que se lhes impõe. O Brasil quer estar ligado a Portugal; mas se o ministério do reinounido, pela sua frouxidão, contribuir para consistência e duração da antiga tirania, o Brasil em pouco tempo proclamará a sua independência".

Não poderia ter sido mais positivo nas afirmações proféticas, que não lhe tinham permitido concluir, retirando-o violentamente da presença do soberano.

Evidentemente, com sua nervosidade, Patroni já expressava o choque de duas mentalidades: a de Portugal, sob o disfarce constitucional, mas mergulhada ainda nos usos absolutistas; a do Brasil, sob a ardência tropical, francamente rebelde, imaginando próxima a aurora da liberdade.

Patroni, descrente, ante o que presenciava na Côrte, onde pleiteara lugar num dos governos ultramarinos que a Constituinte projetava, regressou então ao Pará, onde chegou em janeiro de 1822. A pretexto de cabeça de masorch., que se afirmava planejada pelos irmãos Vasconcelos, fôra-lhe expedido mandado de prisão, revogado pela própria Junta, que não sentira coragem de executar a ordem que baixara. Precedera-o Domingos Simões da Cunha, seu colega de procuradoria na Constituinte Portuguêsa, agora agraciado com o posto de tenente-coronel pela atitude assumida por ocasião dos sucessos de $10^{\circ}$ de janeiro. Simões da Cunha fizera-se acompanhar do tipógrafo e impressor Daniel Garção de Melo, trazendo o material necessário à montagem de uma tipografia, a primeira que a Amazônia conheceu. Patroni vinha encontrar o ambiente carregado. A 10 de dezembro de 1821, depois de uma série de hesitações, de embaraços, tinham sido eleitos em Belém os deputados que - Grã-Pará deveria enviar à Constituinte, reunida em Lisboa: Dom Romualdo de Souza Coelho e o dr. Francis- 
cc; de Souza Moreira, tendo como suplente o desembargador Joaquim Clemente da Silva Pombo. Os eleitos, inegàvelmente, eram figuras de prol na sociedade do extremo-norte. Representavam as classes poderosas, o escol político.

Patroni fôra derrotado no pleito. Talvez influência do ainda poderoso grupo lusíada que já lhe votava restrições... Trazia o coração cheio das injustiças que observara no Reino. Embora sabendo da hostilidade com que o aguardavam, não desanimou na campanha a que viera. Antes, enchera-se de coragem, de decisão, para a luta, que advinhara de vida ou morte, pelas idéias generoass que alimentava.

A 12 de março de 1821, novo govêrno, com o nome de Junta Provisória do Govêrno Civil, sob a presidência do dr. Antônio Correa Lacerda, ficou de posse dos destinos do Pará.

Integraram-na João Pereira da Cunha e Queiroz, secretário; chantre Joaquim Pedro de Moraes Bittencourt, capitão de fragata José Joaquim Rodrigues Lima e capitão Manuel Gomes Pinto.

Com a nova Junta, que direção tomariam os negócios cívico-políticos do Grão-Pará?

Procurando obter a colaboração popular, socegar o espírito público e afirmar claramente da orientação a que ia obedecer, a nova Junta proclamou à Província, concitando-a a manter-se em respeito ao sistema constitucional português. Nada de nervosidades, de hesitações, de atitudes avançadas.

Foi então que Patroni fêz circular "O Paraense", de que era o redator principal. Dispondo da assistência financeira e técnica dos que estavam estabelecidos com a tipografia, "patriarca da imprensa na Amazônia", abriu as baterias do jornal num fogo violento contra o sistema absolutista. Desordenado, mas cheio de ardor cívico, Patroni deve ter provocado, naquela linguagem incendiária que o caracterizava, verdadeiro terror. Os escravos já o apontavam como um redentor. Aos grupos, ouviam a leitura do que lhe saía da pena demolidora sôbre a igualdade entre os homens. Insuflado pelos princípios ardentes que êle pregava, começaram a fugir em massa para o interior, onde organizavam mocambos, ameaçando perturbar a ordem social vigente.

Já se sentia, destarte, claramente, o resultado da ideologia revolucionária de Patroni na atitude que assumiam, desrespeitando sem-cerimoniosamente os brancos, até bem pouco senhores todo poderosos.

Os lusitanos em cujas mãos, recordemos, permaneciam o domínio da terra e do homem, é natural, votavam-lhe agora um ódio feroz. Se êle era a alma de todo o mal-estar que a Província experimentava! 
Para onde se marchava, afinal?

Em abril de 1822 assumiu o comando das armas da Província o brigadeiro José Maria de Moura, mandado especialmente de Pernambuco, onde se distinguira pelas tropelias, como o pulso firme de que a Amazônia estaria carecendo para retomar o caminho da amizade a Portugal.

"Militar brioso, rigorista nos serviços a seu cargo, cioso por demais das suas prerrogativas, conhecedor profundo do seu ofício e da vasta série de cartas régias, resoluções, e ordens atinentes ao serviço, o brigadeiro era de um absolutismo intorsível, diz um cronista, o que o tornava assaz atrabiliário, quando as suas idéias eram discutidas e recalcitradas".

Entrou, de logo, por isso mesmo, em luta acesa com a Junta, prejudicando, com a desarmonia que se abriu entre os órgãos da administração, os interêsse de Portugal no vale.

Não chegou, todavia, a incidentar com Patroni. Porque a 25 de maio, devido a uma devassa procedida em Lisboa, a propósito das palavras que proferira em presença de D. João VI, o demagogo liberal fôra prêso e remetido para Portugal, apesar dos protestos da Junta, que lhe advogou a soltura por não encontrar razão de direito para a providência, determinada pelo ouvidor Francisco Carneiro Pinto Vieira de Melo. Patroni, como cidadão, no Grão-Pará, no juízo da Junta, que assim se divorciava inteiramente do espírito hostil que caracterizava sua antecessora, merecia considerações; tinha cometido crime em Lisboa; em Belém, todavia, por que prendêlio sem ao menos lhe ser dado conhecimento do processo instaurado para que pudesse apresentar defesa? Por que remetê-lo a Lisboa, se o corregedor do crime da Côrte não solicitara a medida, de todo ponto arbitrária?

A opinião pública agitava-se. Tinham começado os receios de violências ante qualquer denúncia que surgisse lá fora contra quem quer que fôsse. Patroni era agora um mártir, em tôrno do qual se movimentaram tôdas as simpatias dos nacionais. Tarde demais, evidentemente, a providência contra $\circ$ ardente jornalista. Assim, num banquete de que filhos da terra tinham participado, as iguarias servidas eram apenas as brasileiras; as européias haviam sido "lançadas pelas janelas". O sentido da independência estava visivelmente criando raízes. Ainda em maio, o Marechal de Campo Manuel Marques d'Elvas, o herói da conquista de Caiena, trouxera, do Rio, "impressos e a notícia da próxima chegada da escuna Maria da Glória com ordem do Príncipe Real para a eleição de deputados ou procuradores às Côrtes do Rio de Janeiro; em junho verificou-se a chegada da escuna; mas não dando a Junta publicidade aos ofí- 
cios que tinha recebido, os partidários da Independência se prevaleceram da conduta do Govêrno para ativamente chamar ao seu partido a opinião dos habitantes da capital".

Nada mais poderia ser feito, no momento, pelos patriotas, devido à manobra de José Maria de Moura, que se apressarí em providenciar, obtendo um pronunciamento da guarnição e da própria Junta contra as ordens de D. Pedro.

A agitação não cerraria, porém, com o contratempo. O Paraense, prêso Patroni, continuava a sair, sob a direção de um sacerdote nativo, o cônego Batista Campos, que assentou baterias alvejando o brigadeiro Moura, contra quem começaram a circular papeluchos insultuosos. Tentaram, a princípio pelo subôrno dos companheiros do sacerdote, reduzí-lo a silêncio. Depois, pelo ataque às oficinas do jornal, « que não se chegou a consumar.

As turras com a Junta, o governador das arm is interferia em tudo. Senhor da fôrça armada, absolutista, intransigente, fiel ao princípio de retôrno do Brasil à condição de colônia, enfeixava realmente nas mãos um poder quase discricionário. Atacado por Batista Campos, que sofreu uma agressão de oficiais portuguêses, declarou-se a 17 de outubro, informado de uma conjura de que participavam o cônego e outros adeptos da independência. E apressando-se em exigir da Junta que, verdade seja proclamada, não assistira o desenrolar dêsses acontecimentos sem lhe atribuir sensacionalismo, exigir, dizíamos, as medidas que lhe pareceram mais urgentes, sugeriu a prisão imediata do cônego e do bacharel Miguel Joaquim de Nogueira, capitão-mor Amadeu José de Oliveira Pantoja, Pedro Rodrigues Henrigues e João Anastácio da Cunha, sôbre os quais recaiam as maiores suspeitas, além da realização de rigorosa devassa acêrca dos perigos eminentes de uma grande revolução que ameaçava destruir o sistema político importado de Portugal.

Depois de alguma resistência, troca de ofícios pouco cortezes entre as duas entidades a que estavam confiados os destinos da Amazônia, procedeu o ouvidor à devassa costumeira, nada se apurando contra os pretensos conjurados. Batista de Campos, a quem se atribuia, assim, a direção do movimento autonomista, atirou-se, porém, dai por diante, à luta, editando proclamações de $\mathrm{D}$. Pedro, numa demonstração cristalina de seus sentimentos e da aspiração popular que ninguém mais podia ignorar. Para o padre, "os papelinhos e discursos impetuosos em Lisbioa tinham preparado a Constituição do Pará", "os papelinhos e discursos do Rio de Janeiro, que êle inseria no seu periódico, hão de 
também pouco a pouco preparar o sistema no Sul para haver a mudança que convier ao Brasil".

Nova denúncia, nova detenção, vieram criar, para o sacerdote, uma situação privilegiada, no consenso do povo. À soltura do cônego, receberam-no com vivas, seguindo-o em massa à "casa onde residia". Batista Campos, José Batista da Silva e Silvestre Antunes Pereira Serra, êste também cônego, os dois colegas de redação, o último a versejar, mais tarde, clandestinamente, exaltando D. Pedro e a independência, numa atividade incessante e frutífera, avançaram, daí por diante, até o aliciamento da soldadesca. Jornais e boletins, trazidos do sul e profusamente espalhados, fizeram ferver o ânimo dos patriotas. Falava-se já, sem constrangimento, em revolução e ajuste de contas com os reinóis.

A sementeira da liberdade caía em terreno de rendimento seguro. Breve apêlo contido num manifesto do Bispo do Pará, numa Pastoral daquele antístite aos fiéis do interior da Província, e na "Proclamação da famosa Velha Amazonas aos seus netos Luso-Americanos", peças tôdas escritas para convocar o povo em tôrno dos absolutistas, não produziam o efeito almejado.

A 30 de dezembro, dirigindo-se ao Ministro do Reino, a Junta Provisória confessava que a Província caminhava para a revolução, sentindo-se o evidente mal-estar criado pelo progresso das idéias de liberdade, idéias que ela considerava dissolventes. Os pasquins incendiários espalharam-se sem que as autoridades conseguissem apurar de onde partiam. A imprensa clandestina circulava em tôda a Província.

Ora, à própria Junta cabia em parte a responsabilidade do nervosismo reinante com a contenda aberta que vinha mantendo com o brigadeiro. E' bem verdade que não deixaria perceber inclinações para com a causa de D. Pedro. Considerava sediciosas as participações, as proclamações e ordens expedidas do Rio. Fiscalizava e apreendia a correspondência oriunda da Côrte imperial. No intuito de sustentar o regime, que estremecia nos seus alicerces, tivera a ingenuidade de pretender constituir uma liga política com Goiás e Mato Grosso, contra a is.filtração dos sentimentos de liberdade semeados pelos patriotas. Revelava, contudo, bem positivamente, vontade de fugir ao jugo férreo dos militaristas que formavam ao lado do brigadeiro e eram a grande fôrça que apoiava o domínio lusitano.

Queixara-se dêle a D. Romualdo Antônio de Seixas, em longo memorial, a 26 de abril, assinalando as dificuldades que marcavam a época. Queixara-se depois, a 20 e a 27 
de junho, ao ministro Ferreira de Araújo Castro, traçando $\checkmark$ panorama da inquietação reinante. $O$ brigadeiro entendiase autônomo, menoscabando da Junta, declarando a Província sob o regime militar. Era, destarte, o mesmo autoritário de Pernambuco, que não admitia razões contrárias às suas. Positivamente, um soldadão, no entender dos governantes civis. Queixara-se, ainda, a 22 de junho, ao Congreso, insistindo nos perigos que decorriam do absolutismo militarista. A solução seria: castigo do brigadeiro ou a substituição da Junta, que se sentia sem segurança para manobrar o barco do Estado, substituição por ela mesmo lembrada a 22 de junho, a 23 de julho, a 16 de novembro. Por fim, a 5 de agôsto, denunciara-o às Côrtes, suplicando-lhes, em nome do povo paraense, "afastar para longe de seus campos êstes tormentos políticos que sobremaneiras o ameação".

De seu lado o brigadeiro dirigia-se às Côrtes, desfiando um rosário de acusações à Junta, que êle indicava como a serviço dos patriotas.

Ao iniciar-se o ano de 1823, era, não há que negar, delicada, para a causa portuguêsa, a situação na Amazônia.

Justamente nesse instante agudo da crise chegara a $\mathrm{Be}$ lém a notícia sensacional da dispensa do brigadeiro, que deveria passar o comando militar ao oficial mais graduado. 0 golpe era forte. Caiu como uma bomba no acampamento reinol. Moura, irritado com a determinação, que lhe encerrava os pruridos políticos, evidentemente, deliberou não se sujeitar ao que lhe pareceu uma providência contrária aos interêsses da pátria. Promoveu entendimento com os seus afeiçoados. $\mathrm{E}$ a 7 de janeiro, atendendo à solicitação de 211 cidadãos, que se dirigiam à Câmara de Belém, para que o brigadeiro permanecesse no cargo, como garantia à ordem e à estabilidade do regime, atendendo, à vontade das fôrças armadas, que também se manifestaram, repetiu o "Fico" do Príncipe Regente.

A Junta não se conformou com os acontecimentos. Era demais. Endereçou nova denúncia, a 12 de fevereiro, ao ministro João Batista de Felgueiras, em Lisboa, contra a ousadia do comandante das armas, pedindo, dois dias depois, demissão coletiva os seus membros que alegaram assim agir porque o exigia "a utilidade pública".

Qual seria o fim de todo êsse desentendimento?

A causa da Independência estava dominando o norte. Colunas patriotas desciam do Piaui sôbre c Maranhão. A Amazônia marcharia com a ideologia revolucionária?

A 27 de fevereiro realizando-se a eleição para a recomposição da Câmara Municipal de Belém, que deveria receber o 
pomposo nome de "Câmara Constitucional", nenhum português conseguiu sufrágios bastantes, o que motivou imediato protesto do grupo reinol perante a Junta. Esta, irresoluta, mal vista, por isso, tanto pelos militaristas como pelos patriotas, declarou-se incompetente para decidir sôbre a anulação do pleito, anulação solicitada pela corrente reinol.

Os escolhidos pelo voto da maioria do corpo de eleitores, numa exteriorização a mais expressiva dos seus sentimentos cívicos, apresentaram-se, para a posse, "com ramos e louros verdes, e foram para suas casas acompanhados por imenso povo, que lançava ao ar girandolas de foguetes". Luminárias, nas casas, completavam as manifestações populares. Os filhos da terra, na linguagem diária, já se chamavam brasileiros, os portuguêses eram os estrangeiros, os europeus.

Seriam precisas maiores provas do estado de ânimo da Amazônia?

A 1 de março de 1823, às 6 horas da manhã, fingindo agir de si própria, a guarnição de Belém, às ordens do coronel João Pereira Vilaça, partidário entusiasta do governador das armas, depôs a Câmara de Belém e a Junta, fazendo constituir novo govêrno sob a presidência de $\mathrm{D}$. Romualdo Antônio Seixas, que parecia um simpatizante aos reinóis.

Os patriotas mais em foco foram presos. A Câmara municipal foi dissolvida, assumindo a edilidade os elementos que a integravam antes do pleito de 27 de fevereiro.

O Paraense, confiscado, mas sob o nome de Luso-Paraense, voltou a circular, atacando a independência, sob a direção de José Ribeiro Guimarães, o denunciante dos irmãos Vasconcelos. O novo govêrno e os militares, em manifestos exaltados, explicaram, a seu modo, as razões da explosão. Antes dos sucessos estivera em Belém, em entendimentos secretos pela causa da liberdade, como agente de D. Pedro, o cidadão José Lins Airosa, acusado de perigoso animador da exaltação. Onde andaria? Que teria feito realmente?

O brigadeiro Moura, que não escondia pendores pelo absolutismo, de fato agora com a direção da Província, preparou-se para reagir contra tôda e qualquer tentativa contrária à sua ideọlogia. Revelou-se, sob êsse aspecto, dum dinamismo espantoso. Reorganizou a tropa, promoveu recrutamentos, aparelhou as fortificações, solicitou auxílios de Lisboa. Seria invencível, imaginava.

Batista Campos foragido, desterrados vários patriotas, a vigilância aumentada com o oferecimento de comerciantes portuguêses, que se constituiram em "Guarda CívicoNacional Voluntária de Cavalaria da cidade", não se podia 
compreender que houvesse mais razões para receios. $\mathrm{O}$ brigadeiro valia como uma garantia à ordem e aos interêsses portuguêses.

Tudo ilusões. Os patriotas, reunidos em casa do imigrado italiano João Batista Baldy, exaltado propagandista da independência, preparavam-se para uma ação enérgica, materializando compromissos assumidos com Airosa. A 14 de abril, às quatro horas da manhã, atacaram o quartel de artilharia, sob o comando do capitão Boaventura Ferreira da Silva, que sublevara parte do $2 .^{\circ}$ regimento de infantaria. O movimento esteve a alastrar-se, com os vivas a d. Pedro, que se ouviram no $3 .^{\circ}$ regimento. Em conseqüência de ferimentos recebidos no choque armado, morreu o tenente-coronel José Antonio Nunes, reinol. Sem as adesões esperadas, os revoltosos, após algumas escaramuças, foram dominados.

Pelo interior, já ardia, a êsse tempo, também, a chama da independência. Em Santarém, em Cametá, em Macapá, em Monte Alegre, as autoridades alarmavam-se com a irradiação revolucionária. Na Vigia, mais viva, crepitante, alarmara a Câmara, que se considerou impotente, pedindo ajuda do govêrno em Belém para conter os extremistas. As denúncias sucediam-se. As violências contra os que eram apontados como simpáticos à independência cresciam dia a dia.

No Marajó, os fugitivos do movimento de 14 de abril, encontrando elementos dispostos à luta, apoderam-se, a 28 de maio, da freguesia de Muaná, sendo, porém, a 7 de junho, batidos por uma coluna partida de Belém, após um combate de quatro horas.

Os deportados para o interior onde iam chegando pregavam a necessidade da independência.

No Rio Negro, a respectiva Junta governativa tomara precauções contra as idéias absolutistas que dominavam Belém. Em plena paz até aquêle instante, a citada circunscrição política do vale conhecia, porém, a marcha avassalante da idéia de independência.

O brigadeiro Moura, prosseguindo sem descanso seu programa de ação, avisado dos progressos das colunas de patriotas que, do Piauí ameaçavam o Maranhão, de onde pcderiam convergir sôbre o Pará, avisado dos progressos alcançados pelos patriotas no interior da Província, procurava dominar a situação, atendendo a tôdas as dificuldades. Para Lisboa, propôs a criação de uma regência para a Amazônia e o Maranhão. Ia ao encôntro do projeto que o deputado João Francisco de Oliveira apresentara às Côrtes, em março, com o apôio das deputações paraenses e 
rionegrenses, que ali se portavam tão contrárias aos sentimentos dos povos que representavam.

Contra os rebeldes, sua ira assumia proporções espantosas. Queria-os passados pelas armas. Felizmente, nem todos os colegas aplaudiram a solução sangrenta. Que fôssem punidos os inimigos da ordem político-social, julgavam, mas sem timanho rigor. Seu partidário era o coronel Vilaça.

Em meio a êsse ambiente de dúvidas, de sobressaltos, a Junta de Justiça, a 16 de maio, condenou à morte os implicridos no movimento de 1 de abril.

D. Romualdo Antônio de Seixas, dos que repeliam, cheios de horror, as penas demasiado severas, assumindo uma atitude altiva, discordou daquela solução. Um grande conselho, que promoveu em palácio, com a presença de tôdas as classes sociais, acompanhou-lhe a indicação serena, que desagradou fundamente os militaristas exaltados, no sentido de se comutar a penalidade numa deportação para Portugal.

$\mathrm{Na}$ galeota Andorinha do Tejo, apesar das ameaças da oficialidade portuguêsa, sèguiram para Lisboa, onde foram recolhidos à prisão de São Julião da Barra, 267 patriotas, dos quais 217 militares e 50 civis.

$\mathrm{O}$ brigadeiro Moura, quase desconhecendo a autoridade da Junta, a quem dava ordens, cumpridas servilmente, sob a alegação de que se tratava de atuar contra elementos facciosos e pelo bem público, imaginando dominada a situação, implantru então na Província o govêrno de fôrça. Ninguém ousava lıvantar-se em contrário. Tudo se fazia à sua ordem. O brigadeiro, atilado, compreendia o perigo de uma facilidade, donde o pulso forte porque marcava a sua atuação.

Sucede, todavia, que a situação não fôra dominada. Para agravá-la, o recrutamento no interior, mesmo violentamente como estava sendo operado, não proporcionava os resultados que se esperavam. Demais, as deserções se registravam dia a dia, cada vez em maior volume. As finanças públicas, definhando, não havia recursos bastantes para as medidas de salvação que se projetavam. Aumentavam, consideràvelmente, nas cercanias de Belém, no Marajó, pelo Tocantins, os mocambos. Os negros aproveitando a desordem do momento, açulados pela idéia de liberdade e de igualdade que ouviam, fugiam para aquelas zonas, criando maiores inquietações. E para o sul, à presença de D. Pedro, a pleitear ajuda para integração da Amazônia ao Império, seguira um emissário dos patriotas, João Roberto 
Ayres Carneiro, ao qual se foram juntar posteriormente Joaquim de Macedo e José Batista da Silva.

$O$ brigadeiro Moura, armado de uma vontade inquebrantável, não se deixava vencer: o recrutamento prosseguiu, contra os mocambos expediu fôrças volantes, recorrendo ao comércio para as despesas com o aparelhamento defensivo da Província. Se sua intervenção iniciada até sôbre as fôrças da marinha, intervenção acatada sem a menor reserva! Era êle, inegàvelmente, um Vice-Rei da Amazônia. E, se assim era, por que, pois, não assumir a direção de direito, dissolvendo a Junta onde encontrava de frente a ponderação perigosa de $D$. Romualdo, já suspeito ao elemento reinol exaltado? Com a chegada do bispo d. Romualdo de Sousa Coelho, sobrindo de D. Romualdo Antônio de Seixas e portador de novas e de documentos sôbre o restabelecimento do absolutismo em Portugal, houve o intento de reorganizar o govêrno. Ficou assentado, todavia, em reunião no Palácio governamental, a 5 de agôsto, que se aguardassem maiores esclarecimentos e instruções de Lisboa. Moura, com a nova sensacional, exultava. Se êle jamais escondera suas tendências absolutistas!

José Bonifácio, em nome do Imperador, preocupado com o problema do reatamento da unidade territorial, dirigira-se à Junta concitando-a a aceitar a situação criada pelo 7 de setembro. Sem coragem para um passo decisivo, a Junta respondeu pela negativa. Evidentemente não expressava a vontade de seus governados.

Rearticulavam-se os patriotas para novo pronunciamento quando, a 11 de agôsto de 1823 , fundeou no pôrto de Belém o brigue de guerra Maranhão, hasteando o pavilhão brasileiro, sob o comando de John Pascoe Grenfell.

A cidade encheu-se de temores. Os patriotas, que, insistamos, já se vinham preparando para novo golpe, cientes do que ocorria, deram plena expansão aos seus sentimentos. $O$ brigadeiro Moura, imaginando ainda oportuna uma ação armada contra o enviado de D. Pedro, convocou os militares para o quartel general. Convidou a Junta para deliberar. Esta recusando comparecer, promoveu a reunião de um conselho de tôdas as classes, em Palácio, à noite.

Contra o voto do tenente-coronel Teodósio Constantino de Chermont e do brigadeiro Moura, que deu motivo em separodo, por escrito, a assembléia tomou conhecimento da intimação de Grenfell, em nome do almirante Cochrane, que aquêle, num ardil louvável, afirmava estar com poderosa esquadra fundeada na barra. E por entre aclamaçôes ruidosas, declarou imediatamente a adesão da Província à causa da Independência. 
O brigadeiro Moura, de comparsaria com o Coronel Vilaça, uma vez esclarecido que Cochrane não balançava os seus navios nas águas do Amazonas, mas em São Luís, procurou articular, com a ajuda financeira de comerciantes portuguêses, um movimento restaurador. Sebastianismo, evidentemente. Denunciados, presos ambos, a bordo do brigue Maranhão, abortou a intentona, que deveria explodir a 15 de agôsto.

Nessa data, no Palácio do Govêrno, na sala docel, realizouse $o$ ato solene e oficial da adesão do Grão-Pará à Independência, com a aclamação de D. Pedro como $10^{\circ}$ Imperador Constitucional do Brasil, seguindo-se, na catedral, um Te Deum Laudamus.

A vibração popular era intensa. Belém derramou-se em expansões de alegria. No interior, a adesão processou-se mais ou menos serenamente, substituindo-se em tôdas as Câmaras o elemento reinol.

O Rio Negro aceitou os fatos consumados. Sua situação geográfica colocou a Capitania, que se considera "Província Privilegiada", numa situação tôda especial, impedindo-a de exaltações, conquanto sua Junta Governativa tivesse assumido atitude de defesa, guarnecendo Parintins contra a política absolutista que o brigadeiro Moura implantara em Belém.

A 9 de novembro, no Logar da Barra, hoje a cidade de Manaus, que servia de sede à Junta Governativa organizada em 3 de junho de 1822, o povo da Capitania dava sua adesão entusiástica, que teve caráter oficial a 22 de novembro, reorganizando-se, a essa altura, o govêrno, que passou a mãos dos homens ligados ao meio pelo nascimento e pelos melhores interêsses coletivos, sob a presidência de João de Souza de Azevedo, nascido em Barcelos e cujos descendentes ligamse presentemente o velho tronco paulista, destarte inaugurando-se no extremo norte a fase nova da administração ficar confiada a quem realmente devia ter a direção da coisa pública num sistema cujo fundamento imediato era evidentemente, o da entrega da terra a seus filhos.

A independência, na Amazônia, semeada com os padecimentos dos patriotas que pagavam o seu crime de amor à liberdade nas prisões de Portugal, pregada em seu início pelos Patroni, pelos Batista Campos, foi uma conquista trabalhosa que nos autoriza a discordância, insistimos, em que nos declaramos a propósito do pronunciamento dos historiadores que entendem a nossa autonomia como uma ocorrência sem côr, obtida suavemente. 
No extremo norte do Brasil, como noutras áreas políticas, homens cheios de fé, grupos sociais dominados pelo ideal da liberdade, comportaram-se altiviamente, combatendo nos campos de batalha, nos entreveros de imprensa, nos pronunciamentos de edilidades, no trabalho subterrâneo.

A incorporação da Amazônia ao Império, tendo, nos sucessos que tentamos sumariar, seus primeiros episódios, ia ser, tc.davia, tarefa ensangüentada nos dias seguintes ao 15 de agôsto, dado que a multidão nativa, imaginando que o poder lhe cabia sem possibilidades para a permanência daqueles elementos contra os quais lutara tão decididamente, considerou-se, de lıgo, traída em seus ideais políticos e se lançou às jornadas armadas, sob a direção dos mesmos homens saídos do povo, prenunciando as horas intranqüilas da grande explosão social que foi a Cabanagem. Empreendimento cívico assinalado por suas características profundamente populares, a incorporação da Amazônia ao Império Brasileiro era uma façanha em que não tinham parte memorável senão aqueles nativos que não dispunham, até então, de bem-estar material. Antes de constituir página impressiva de história política, o episódio possui côr social, que evidentemente, faltou ao acontecimento nas outras áreas brasileiras. Aquela sociedade mestiçada, de gentio e reinol, depois das emprêsas descobridoras, e da irradiação territorial, depois de ter alimentado o mercado europeu com a produção de sua atividade econômica mesmo na forma primária que a distinguiu mais vivamente, vibrara com a independência. Resistira ao dominador reinol por que entendia que essa era a atitude que devia assumir. Vencendo-o, porém, imaginava ter dado um passo na dirđção de uma liberdade que lhe assegurasse o bem-estar material e espiritual que só o europeu desfrutava. Incorporando a região ao Império, estabelecido por Pedro I, completava com seu gesto, a unidade territorial que estivera a pique de romper-se. A Amazônia, criada para o império português no decorrer de dois séculos acesos de luta contra estrangeiros e contra a natureza agressiva, mantinha-se, destarte, firme ao lado das outras unidades políticas que passavam a constituir o estado soberano brasileiro. A distância política em que crescera como estado distinto do Brasil cessara pela vontade de seus filhos. A multidão mestiça queria ser brasileira.

\footnotetext{
ARTHUR CEZAR FERREIRA REIS Membro do Instituto Mistórico e Geográfico Brasileiro.
} 